\title{
Pelatihan Komputer Dan Internet Untuk Perangkat Desa Pancoran Kecamatan Bondowoso Kabupaten Bondowoso
}

\author{
Daryanto $^{1^{*}}$, Zainul Arifin ${ }^{2}$ \\ ${ }^{1,2}$ Universitas Muhammadiyah Jember \\ E-mail: ${ }^{1}$ daryanto@unmuhjember.ac.id, ${ }^{2}$ zainularifin@unmuhjember.ac.id
}

\begin{abstract}
Administratively, Pancoran Village is led by a Village Head who leads 12 section heads, consisting of 1 secretary, 7 heads of affairs, and 4 hamlet heads. Each of these section heads is assisted by other village officials to carry out their duties in community service. In carrying out its obligations, especially those related to village administration and licensing, ideally village officials have competence in the computer sector. However, from the village apparatus report, the village apparatus who mastered basic computer material, in this case was Microsoft Office (Word, Power Point, and Excel), only one person was not optimal.
\end{abstract}

Keywords : computer, village apparatus

\begin{abstract}
Abstrak
Secara administratif, Desa Pancoran dipimpin oleh Kepala Desa yang memimpin 12 orang kepala bagian, yang terdiri dari 1 sekretaris, 7 Kepala urusan, dan 4 Kepala dusun. Masing-masing kepala bagian tersebut dibantu perangkat desa lainnya untuk melaksanakan tugas dalam pelayanan masyarakat. Dalam melaksanakan kewajibannya, khususnya yang berkaitan dengan administrasi desa dan perijinan, idealnya perangkat desa mempunyai kompentensi dalam bidang komputer. Namun demikian, dari laporan perangkat desa, perangkat desa yang menguasai materi komputer dasar, dalam hal ini adalah microsoft office (word, power point, dan excel)hanya satu orang saja dan itupun belum maksimal.
\end{abstract}

Kata Kunci : komputer, perangkat desa

*Penulis Korespondensi : Daryanto

\section{PENDAHULUAN}

Desa Pancoran merupakan salah satu Desa dari 4 Desa dan 7 Kelurahan yang ada di Kecamatan Bondowoso, secara geografis Desa Pancoran terletak pada ketinggian 259 Meter diatas 'permukaaan laut Luas Wilayah 369, 3 HA. dengan mayoritas masyarakat beretnis Madura. Adapun batas-batas wilayah Desa Pancoran adalah: (1) Bagian utara berbatasan dengan desa Sukowiryo, (2) Bagian timur berbatasan dengan desa Kejawan Kecamatan Grujugan, (3) Bagian selatan berbatasan dengan desa Taman Kecamatan Grujugan, (4) Bagian barat berbatasan dengan desa Jetis Kecamatan Grujugan.

Mata pencaharian penduduk Desa Pancoran sebagian besar di sektor pertanian dan perkebunan. Hasil utama pertanian desa Pancoran adalah padi, sedangkan hasil utama perkebunan adalah tebu. Adapun sisa lahan di Desa Pancoran dimanfaatkan oleh penduduk untuk rumah dan untuk menanam tanaman penghasil kayu, salah satunya adalah Sengon. 
Adapun mata pencaharian lainnya antara lain adalah pedagang, pegawai negeri, tukang cukur, tukang listrik, servis alat elektronik, mekanik, tukang kayu atau mebel, dan penjahit. Pendidikan di desa Pancoran merupakan unsur yang diperhatikan oleh masyarakat. Hal ini dapat dilihat dari tingkat pendidikan yang dimiliki oleh penduduk sudah sampai tingkat perguruan tinggi. Di desa ini juga sudah ditemukan beberapa sekolah dasar (SD) dan sekolah menengah pertama (SMP).

Sedangkan penduduk dengan tingkat pendidikan sekolah menengah atas (SMA) dan Perguruan Tinggi memilih untuk melanjutkan pendidikannya di luar Desa Pancoran, karena memang belum ada SMA dan Perguruan Tinggi di Desa ini. Dengan tingkat pendidikan yang dimiliki tersebut, diharapkan penduduk usia produktif di desa Pancoran memiliki pengetahuan dan keterampilan untuk menunjang pekerjaannya.

Secara administratif, Desa Pancoran dipimpin oleh Kepala Desa yang memimpin 12 orang kepala bagian, yang terdiri dari 1 sekretaris, 7 Kepala urusan, dan 4 Kepala dusun. Masing-masing kepala bagian tersebut dibantu perangkat desa lainnya untuk melaksanakan tugas dalam pelayanan masyarakat. Dalam melaksanakan kewajibannya, khususnya yang berkaitan dengan administrasi desa dan perijinan, idealnya perangkat desa mempunyai kompentensi dalam bidang komputer. Namun demikian, dari laporan perangkat desa, perangkat desa yang menguasai materi komputer dasar, dalam hal ini adalah microsoft office (word, power point, dan excel) hanya satu orang saja dan itupun belum maksimal.

Permasalahan mitra pada Program Kemitraan Masyarakat Stimulus ini adalah dari segi pengelolaan administrasi desa sementara hanya melakukan pencatatan surat masuk dan keluar untuk administrasi masih dilakukan manual, sehingga pengelolaan administrasi desa untuk pembuatan surat masuk dan keluar belum dapat diketahui secara jelas.

Justifikasi pengusul bersama mitra tentang permasalahan dalam Program Kemitraan Masyarakat Stimulus kali ini adalah Masih kurangnya wawasan mitra terutama tentang pengelolaan administrasis desa untuk pembuatan surat masuk dan keluar. Masih terbatasnya produk teknologi informasi yang digunakan, sehingga melalui kegiatan ini akan diwujudkan tersedianya aplikasi sederhana untuk mencatat dan memantau kondisi pengelolaan administrasi desa.

\section{METODE}

Metode pelaksanaan PKM dilakukan berdasarkan solusi permasalahan yang telah dijelaskan. Tabel 1 menunjukkan tahapan kegiatan tersebut. Model pelaksanaan kegiatan PKM ini terdiri dari sosialisasi, pembuatan aplikasi, dan pelatihan. Tahapan kegiatan dilakukan secara berurutan dimulai dengan tahapan sosialisasi, baik untuk konsep keuangan maupun pencatatan keuangan, kemudian dilakukan perancangan dan pembuatan aplikasi. Kegiatan terakhir adalah pelatihan penggunaan aplikasi yang sekaligus mencakup pelatihan pengelolaan administrasi desa.

Pada tahap sosialisasi tim pengusul akan memberikan wawasan dan pengetahuan tentang pengelolaan administrasi desa pada umumnya, pada tahap ini juga tim pengusul melakukan oservasi terhadap pola pencatatan surat masuk dan keluar yang dilakukan atau yang dapat diterapkan pada mitra. Pada tahap kegiatan penyediaan aplikasi, tim pengusul akan melakukan perancangan berdasarkan hasil observasi, dan ditindaklanjuti dengan pembuatan aplikasi. Proses pemberian keterampilan dilakukan terakhir yaitu pada tahap kegiatan pelatihan dan pendampingan. Lokasi untuk pelaksanaan masing - masing kegiatan akan dilakukan pada lokasi mitra.

\section{HASIL DAN PEMBAHASAN}

Pada tahap ini Peserta juga diberikan pemahaman mengenai pentingnya bukti uang masuk dan uang keluar, dan sekaligus melakukan pengarsipan atas bukti tersebut sebagai langkah awal untuk memulai pencatatan pembukuan. Kegiatan ini dilaksanakan pada hari selasa, tanggal 6 April 2021 
dimulai dari jam 09.00 sampai jam 11.00. Peserta mengikuti kegiatan dengan antusias, hal ini dapat dilihat dari peserta yang menyimak penjelasan dengan baik. Peserta juga melanjutkan berdiskusi dengan pemateri setelah acara selesai. Sehingga dapat diindikasikan bahwa peserta sosialisai menyambut positif kegiatan pengabdian kepada masyarakat.

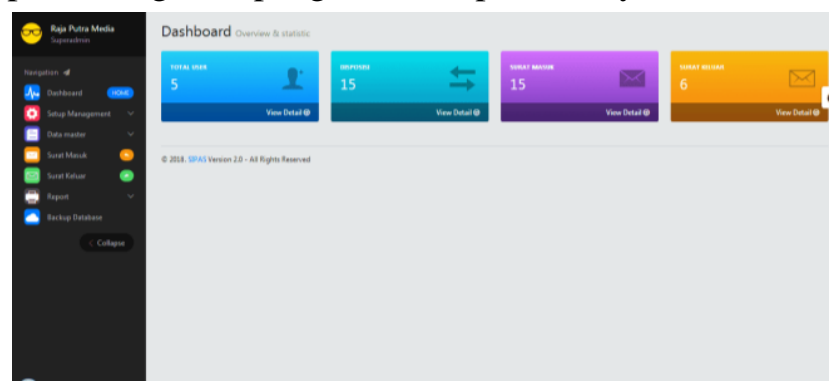

Gambar 1. Tampilan Dashboard Aplikasi surat masuk /keluar

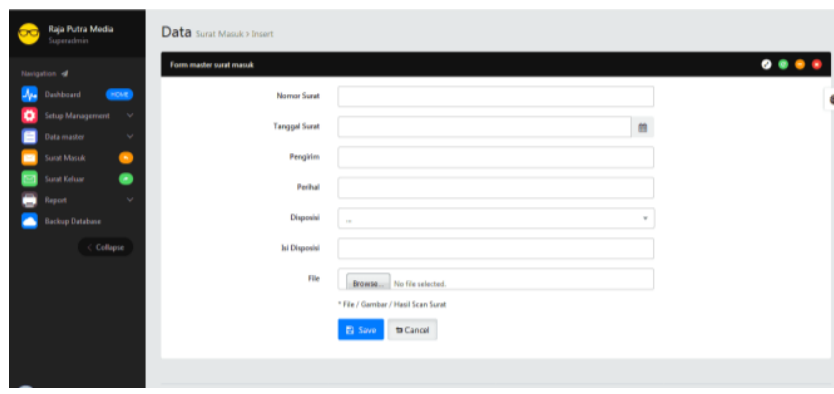

Gambar 2. Form Input Data Surat Masuk

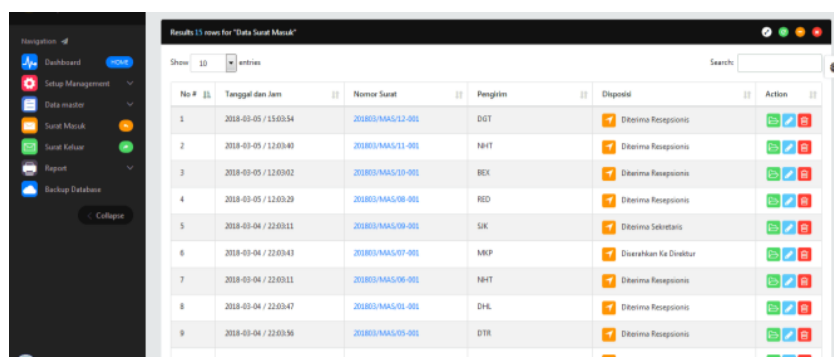

Gambar 3. Data Arsip Surat Masuk/Keluar

\section{KESIMPULAN}

Kesimpulan dari kegiatan ini yaitu wawasan mitra tentang konsep pengelolaan administrasi desa bertambah, Pemanfaatan teknologi informasi dalam pengelolaan administrasi desa membantu dari segi kemudahan dan menelusuri kembali informasi yang telah dicatat sebelumnya, Keterampilan mitra bertambah dalam pengelolaan administrasi desa sebagai penunjang kegiatan bisnisnya.

Saran dari kegiatan ini yaitu, beberapa perbaikan terhadap fitur aplikasi yang belum tersedia dapat dikembangkan dan ditambah, seperti tingkat level administrator.

\section{UCAPAN TERIMA KASIH}

Ucapan terima kasih tak terhingga kami sampaikan kepada semua pihak yang telah membantu dan berpartisipasi dalam kegiatan pengabdian masyarakat ini, khususnya pihak mitra pengabdian dan kampus Universitas Muhammadiyah Jember.

\section{DAFTAR PUSTAKA}

Diansyah, R., Syahril, Aryanto, Arribe, E., \& Winarso, D. (2017). PENGUATAN UMKM MELALUI PELATIHAN BLOG. Jurnal Pengabdian Untuk $M u$ negeRI.

Dinas Koperasi dan Usaha Mikro Kabupaten Jember. (2017). Perubahan Rencana Strategis Tahun 20162021. Jember: Pemerintah Kabupaten Jember.

Lin, C. Y.-Y. (1998). Success Factors of Small- and Medium-Sized Enterprises in Taiwan An Analysis of Cases. Journal of Small Business Management, XXXVI, 43-56.

Lubis, T. A., \& Junaidi. (2016). Pemanfaatan Teknologi Informasi pada Usaha Mikro Kecil dan Menengah di Kota Jambi. Jurnal Perspektif Pembiayaan dan Pembangunan Daerah, 163-174.

Nurfriani, V., Paramu, H., \& Utami, E. S. (2014). Analisis Kinerja Usaha Mikro, Kecil dan Menengah (UMKM) Dengan dan Tanpa Pinjaman Di Kabupaten Jember. Jember, Jawa Timur, Indonesia.

Syarizka, D. (2018, February 28). bisnis.com. Diambil kembali dari ekonomi.bisnis.com: https://ekonomi.bisnis.com/read/20180228/12/744047/ pemerintah-targetkan-6-juta-umkm-go- digital-tahunini 